\title{
Avian species richness and abundance at Lake Constance: diverging long-term trends in Passerines and Nonpasserines
}

\author{
Hans-Günther Bauer • Nicole Lemoine • \\ Markus Peintinger
}

Received: 13 September 2007/Revised: 16 November 2007 / Accepted: 19 November 2007 / Published online: 5 February 2008 (C) Dt. Ornithologen-Gesellschaft e.V. 2008

\begin{abstract}
In Central Europe, massive losses in species richness of breeding birds have been documented in the last decades, but the question arises whether species richness is currently still decreasing or again increasing due to conservation efforts. In this study, we investigated regional and local species richness as well as mean number of breeding pairs and mean biomass per tetrad over a period of some 20 years at Lake Constance. Three quantitative censuses of 303 tetrads $\left(2 \times 2 \mathrm{~km}^{2}\right)$ repeated at 10-year intervals (1980-1981, 1990-1992, 2000-2002) revealed an increase in regional species richness (total number of breeding species). At the same time, however, a strong decline in local species richness (number of breeding species per tetrad), number of breeding pairs, and estimated biomass were observed. Changes of species richness differed markedly between Nonpasserine and Passerine birds. Whereas species richness of Nonpasserines remained constant from 1980 to 1990 , and even increased between 1990 and 2000, that of Passerines decreased in both
\end{abstract}

Communicated by J. Fjeldså.

H.-G. Bauer $(\bowtie)$

Vogelwarte Radolfzell, Max-Planck-Institute for Ornithology,

Schlossallee 2, 78315 Radolfzell, Germany

e-mail: bauer@orn.mpg.de

H.-G. Bauer

Ornithologische Arbeitsgemeinschaft Bodensee (OAB),

Beyerlestr. 22, 78464 Konstanz, Germany

N. Lemoine

Dech.-Kamper-Str. 26, 52538 Selfkant, Germany

M. Peintinger

Institute of Environmental Sciences, University of Zürich,

Winterthurerstr. 190, 8057 Zurich, Switzerland periods. This indicates that effects of conservation efforts apparently eclipse more general effects of climate and habitat change in Nonpasserines. The massive abundance and biomass losses observed in formerly common Passerine species are not compensated by gains in populations of Nonpasserine species. The results of the three bird censuses at Lake Constance imply that ongoing habitat degradation and human impacts as well as increasing effects of climate change are the main drivers of the observed population changes.

Keywords Breeding birds · Biodiversity . Central Europe $\cdot$ Monitoring

\section{Introduction}

In order to be able to halt biodiversity loss by 2010, conservationists "must first identify which species or species groups are in decline" (Sanderson et al. 2006). Yet, considering the manifold aspects affecting bird distribution and abundance, and the diverging trends observed, the question arises whether total species diversity in Central Europe is currently still decreasing or again increasing. In Europe, avian diversity in agricultural landscapes has declined markedly during the last decades as documented in numerous studies and reviews (e.g., Böhning-Gaese and Bauer 1996; Pain and Pienkowski 1997; BirdLife International 2004; Gregory et al. 2004; Newton 2004; Bauer et al. 2005a, b; PECBM 2006). Next to habitat degradation and fragmentation, reductions of biodiversity have also increasingly been attributed to climate change (e.g., Walther et al. 2002; Julliard et al. 2003; Travis 2003). These effects, in addition to human interference (e.g., hunting), are thought to be responsible 
for the recent massive declines observed in Afro-Palearctic long-distance migrants (Böhning-Gaese and Bauer 1996; Berthold 2001; BirdLife International 2004; Sanderson et al. 2006). On the other hand, populations of some flagship species of nature conservation such as White Stork Ciconia ciconia, Osprey Pandion haliaetus, Crane Grus grus, and White-tailed Eagle Haliaeetus albicilla, etc., have increased during the last decades and expanded their areas (Bauer et al. 2005b). Furthermore, transportation has led to introductions and range expansions of a considerable number of exotic species into Europe (McKinney and Lockwood 1999).

To study changes in avian species richness in a Central European landscape, we used grid census data of the international ornithological working group OAB (Ornithologische Arbeitsgemeinschaft Bodensee) at Lake Constance from 1980 to 1981,1990 to 1992 , and 2000 to 2002. Previous studies here had shown (1) that species richness per unit area had decreased during the first 10-year period (Böhning-Gaese and Bauer 1996), (2) that in both periods a strong decline of long-distance migrants and of farmland species had occurred (Bauer and Heine 1992; Böhning-Gaese and Bauer 1996; Bauer et al. 2005a; Lemoine et al. 2007), and (3) that the impact of climate change on species composition was evident during the second but not during the first period (Bauer et al. 2005a; Lemoine et al. 2007).

In the present study, the first objective was to investigate whether total number of species (= regional species richness) or mean number of species per tetrad (= local species richness) had changed any further after the second census, and whether regional abundance and biomass in avian populations had also been negatively affected. Since Nonpasserines and Passerines may differ markedly in distribution patterns and population dynamics, the second objective of this study was to analyse both taxonomic groups separately. We expected diverging trends because both groups differ in average body size, which in turn may influence intrinsic population growth rate, longevity, and territory size (Pimm et al. 1988); and this should have consequences for population dynamics and changes of species richness.

\section{Methods}

Species richness and regional abundance of breeding birds were estimated for three census periods at Lake Constance (SW-Germany, W-Austria, N-Switzerland) covering an area of $1,120 \mathrm{~km}^{2}$. The Lake Constance region is characterised by a mosaic of forests, arable fields, grasslands, orchards, fruit plantations, wetlands and urban areas. Using line transects, the abundance of all breeding bird species were examined in 1980-1981, 1990-1992, and 2000-2002 (for simplicity hereafter referred to as 1980, 1990, and 2000, respectively). For each census period, 303 tetrads $\left(2 \times 2 \mathrm{~km}^{2}\right)$ were visited five times during favourable weather conditions between end of March and middle of June. During each visit different line transects (of c. $4 \mathrm{~km}$ length) with recording distances of $50 \mathrm{~m}$ at either side were chosen, resulting in a coverage of 40 ha per visit. Thus, over five visits about half of the tetrads were sampled. Total abundance of territorial birds was estimated in six abundance classes. For number of breeding pairs and biomass we replaced abundance classes with the geometric mean of their boundaries $(1.7,5.5,17.3,54.8,173.2$, and 547.7 breeding birds, respectively). For further methodical details, see Schuster (1986), Bauer and Heine (1992), Böhning-Gaese and Bauer (1996), Bauer et al. (2005a), and Lemoine et al. (2007).

In order to calculate biomass, we multiplied the number of breeding individuals per species and tetrad (by doubling the recorded number of breeding pairs) with the species' mean body mass using data from Bezzel $(1985,1993)$. We used paired $t$-tests for comparison of the variables between the census periods 1980-1990, 1990-2000, and the total period 1980-2000, respectively. We also tested for observer effects by comparing tetrads censused by the same person (1980-1990: $n=79$; 1990-2000: $n=55$; 1980 2000: $n=95$ ) with tetrads censused by different persons in the respective survey periods (1980-1990: $n=224$; 1990 2000: $n=248 ; 1980-2000: n=208)$. The analyses were made for all species combined, and for Passerines and Nonpasserines separately, but we could find no significant observer effects at all.

\section{Results}

At Lake Constance, avian species richness increased on a regional scale (total area of $1,120 \mathrm{~km}^{2}$ ) from 141 (1980) and 146 (1990) to 154 (2000) breeding species. This increase is mainly caused by Nonpasserine birds (1980: 61; 1990: 65; and 2000: 72 species). Yet, local species richness (per $4 \mathrm{~km}^{2}$ tetrad) decreased from 1980 to $1990(P<0.10)$ and again slightly but not significantly from 1990 to 2000 (Fig. 1, Table 1); for both periods combined (1980-2000) the decline was highly significant $(P<0.01)$. Changes of local species richness differed considerably between the two taxonomic groups considered. In the Nonpasserines, local species richness remained constant from 1980 to 1990 and increased between 1990 and $2000(P<0.001)$ and, consequently, also for the total census period 1980-2000 $(P<0.01)$. In the Passerines, a significant decline of local species richness was observed in both decades as well as for the whole period (see Table 1). 
Fig. 1 Changes in mean species richness $(+\mathrm{SE})$ per unit area at Lake Constance (303 tetrads of $2 \times 2 \mathrm{~km}$ ) of all species combined, and of Nonpasserines and Passerines separately. Significant differences for the periods 1980-1990, 1990-2000, and 1980-2000, respectively, are indicated by: ${ }^{+} P<0.10$, $* P<0.05, * * P<0.01$, $* * * P<0.001$ (see Table 1)
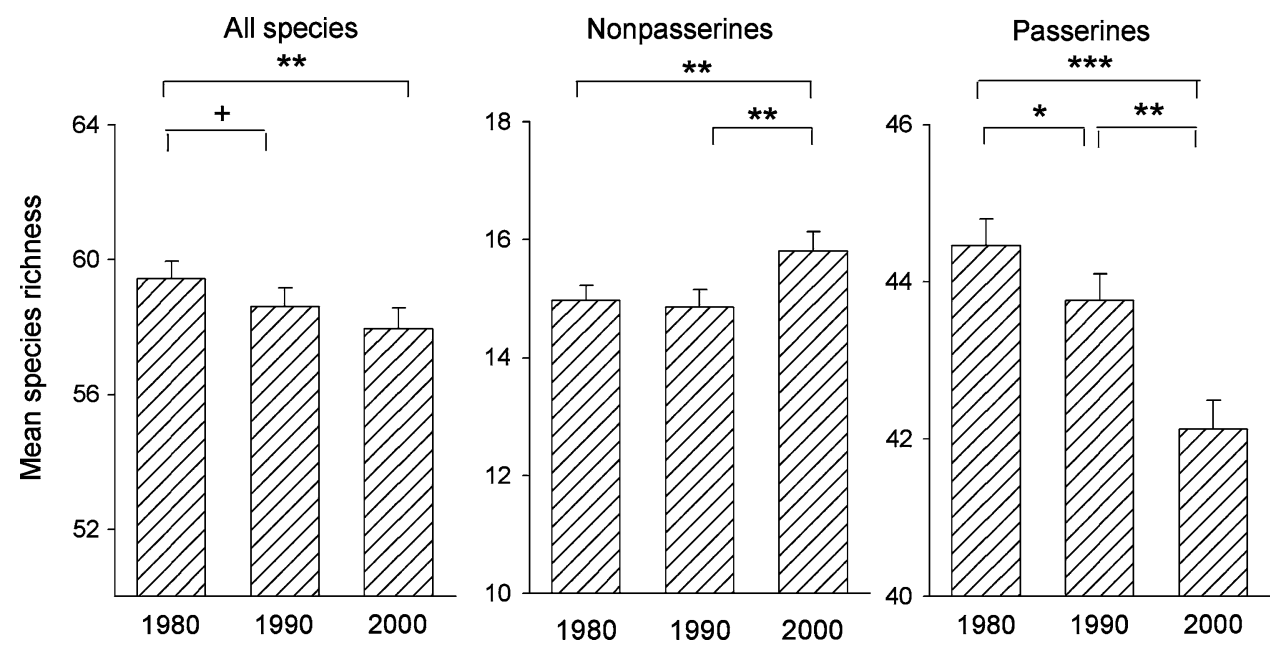

The mean number of breeding bird pairs per tetrad decreased continuously between 1980-1990 $(P<0.01)$ and 1990-2000 $(P<0.001)$, and for the whole period 1980-2000 at $P<0.001$ (Fig. 2, Table 1). However, no significant changes were detected for Nonpasserines. The negative trend observed was solely due to strong declines in Passerine numbers, whereas the comparatively low total number of breeding Nonpasserines had little effect on this pattern. The estimated total biomass per tetrad decreased between 1980 and $1990(P<0.05)$, but not between 1990 and 2000. Again, the decrease was significant $(P=0.014)$ for the total period $1980-2000$ (Table 1).

\section{Discussion}

At Lake Constance, regional species richness of breeding birds has increased between 1980 and 2000, achieving a net gain of 13 species over the total area of some $1,100 \mathrm{~km}^{2}$. However, over the same period, local species richness declined highly significantly between 1980 and 2000 (see Böhning-Gaese and Bauer 1996; Böhning-Gaese 1997; Bauer et al. 2005a). To add to the complexity, the separate analysis of two taxonomic groups, Nonpasserines and Passerines, showed considerably diverging patterns of changes. First, we found an increase in regional species richness in Nonpasserines, whereas in Passerines regional species richness remained almost constant. Second, local species richness of Nonpasserines increased during the second decade while that of Passerines still decreased (and even more strongly than in the first decade).

Evidently, if the results of increasing regional diversity at Lake Constance were discussed on their own, the inferences for nature conservation would wrongly imply an improved situation. However, local diversity showed a marked decrease during the same time period, indicating a
Table 1 Summary of the results (paired $t$-test) for changes in species richness, number of breeding pairs and estimated biomass in 303 tetrads $(2 \times 2 \mathrm{~km})$ at Lake Constance for two time periods, separately, and for total period (1980-2000)

\begin{tabular}{|c|c|c|c|c|c|c|}
\hline & \multicolumn{2}{|c|}{$1980-1990$} & \multicolumn{2}{|c|}{$1990-2000$} & \multicolumn{2}{|c|}{$1980-2000$} \\
\hline & $t$ & $P$ & $t$ & $P$ & $t$ & $P$ \\
\hline \multicolumn{7}{|c|}{ Species richness per tetrad } \\
\hline All species & -1.83 & 0.07 & -1.43 & 0.15 & -3.0 & $<\mathbf{0 . 0 1}$ \\
\hline Nonpasseriformes & -0.48 & 0.63 & 3.82 & $<\mathbf{0 . 0 1}$ & 3.01 & $<\mathbf{0 . 0 1}$ \\
\hline Passeriformes & -2.39 & 0.02 & -5.44 & $<\mathbf{0 . 0 1}$ & -7.62 & $<\mathbf{0 . 0 0 1}$ \\
\hline \multicolumn{7}{|c|}{ Breeding pairs per tetrad } \\
\hline All species & -3.09 & $<\mathbf{0 . 0 1}$ & -3.42 & $<\mathbf{0 . 0 0 1}$ & -5.99 & $<\mathbf{0 . 0 0 1}$ \\
\hline Nonpasseriformes & 0.41 & 0.68 & -0.77 & 0.44 & -0.34 & 0.73 \\
\hline Passeriformes & -3.42 & $<\mathbf{0 . 0 0 1}$ & -3.56 & $<\mathbf{0 . 0 0 1}$ & -6.21 & $<\mathbf{0 . 0 0 1}$ \\
\hline $\begin{array}{l}\text { Community } \\
\text { biomass } \\
\text { per tetrad }\end{array}$ & 2.0 & 0.046 & -0.77 & 0.44 & 2.47 & 0.014 \\
\hline
\end{tabular}

$P$-values in bold are significant at $P<0.05$
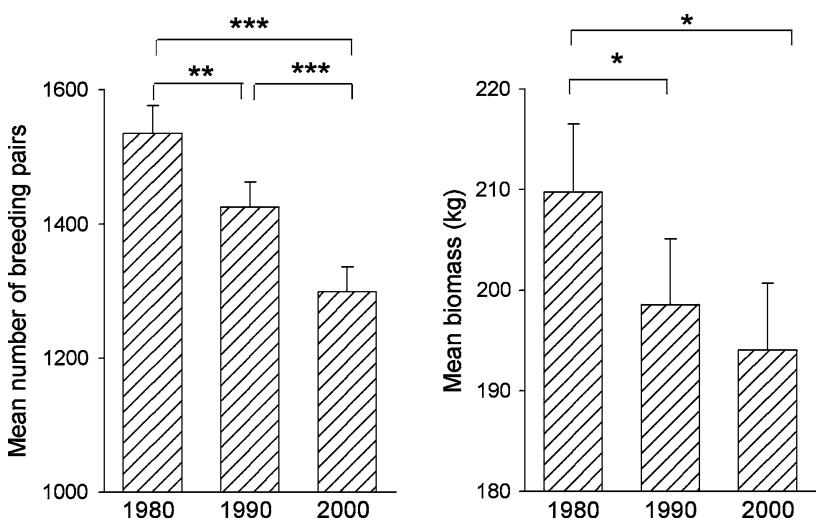

Fig. 2 Changes in the mean number (+SE) of breeding pairs and of mean biomass in 303 tetrads $(2 \times 2 \mathrm{~km})$ at Lake Constance. Significant differences for the periods 1980-1990, 1990-2000, and 1980-2000, respectively, are indicated by: $* P<0.05$, $* * P<0.01$, $* * * P<0.001$ (see Table 1) 
negative development, i.e., a decline in richness per unit area. Therefore, it can be dangerous to infer from increased species richness at a regional scale that the decline of bird populations has halted and conservation measures have been successful. This is even more apparent if the study of species richness is confined to nature conservation areas (for Lake Constance, cf. Schuster and Brall 2007). But how are these diverging trends explained? The conservation of large wetland areas at Lake Constance and the massively reduced hunting pressure since the early 1970 s have led to a recovery and a re-establishment of larger bird species. The increase in Nonpasserine species richness corresponds well with: (1) range expansions and population increases of wetland species (especially cormorants, herons, ducks) due to conservation measures (reduction in disturbance and hunting, wetland management) and to eutrophication (BirdLife International 2004; Bauer et al. 2005b); (2) the recovery of raptor species which are no longer persecuted and also profited greatly from other conservation measures and from reintroductions; and (3) the appearance of several exotic species, which in general stem predominantly from Nonpasserine groups (Anseriformes, Galliformes, and Psittaciformes) (Bauer et al. 2005b), and often profit from environmental modifications and human transportation (McKinney and Lockwood 1999).

The decrease of Passerine species richness, on the other hand, seems to be related to a range of factors: (1) to the continuing strong decline of formerly very common farmland species (Bauer et al. 2005a); (2) to massive losses in long-distance migrants (Sanderson et al. 2006; Lemoine et al. 2007), of which Nonpasserine species are much less affected; and (3) to strong declines in other common songbirds, which are either poorly understood or, at least in part, assignable to direct and indirect impacts of climate change (Travis 2003; Møller et al. 2004; Bauer et al. 2005b).

The observed decrease of breeding pair abundance and of avian biomass at Lake Constance might indicate a resource limitation in the breeding grounds, be it availability of food or breeding habitat. Human impact in the strongly modified landscape at Lake Constance (Lemoine et al. 2007) has led to a further degradation of breeding habitats (e.g., intensification of land use, eutrophication), to continuing urbanisation (habitat loss) and to the fragmentation of habitats. In parallel, the decline might have been intensified by habitat deterioration on the wintering grounds and/or an increased mortality of long-distance migrants. The observed declines of African winterers were disproportionally large as compared with those of residents and short-distance migrants, with species wintering (1) in the savannah region or (2) in the tropics and southern Africa being equally affected (H.-G. Bauer et al., unpublished data). However, as the proportion of long-distance migrants in the avian community at Lake Constance is comparatively low, decreasing continuously from $12 \%$ in 1980 to $8 \%$ in 2000 (Bauer et al. 2005a), this can only partly explain the observed changes. The largest bird populations at Lake Constance are comprised by residents and short-distance migrants which are stable or even increasing (Bauer et al. 2005a; Lemoine et al. 2007), and apparently favoured by climate change (Møller et al. 2004).

There is a marked difference in abundance changes between various habitat types. Recently, the abundances of urban and of wetland species have shown relatively positive population changes at Lake Constance (Bauer et al. 2005a), confirming trends in neighbouring regions (e.g., Zbinden et al. 2005a, b) and in Europe as a whole (e.g., PECBM 2006). In forests, the worst declines have probably occurred in earlier decades or centuries. In the already impoverished forest avifauna of Central Europe we currently find a larger number of species with population increases than with population decreases (Flade and Schwarz 2004; Zbinden et al. 2005b; Bauer et al. 2005a), although the European Common Bird Indicator implies a decline in forest birds by 13\% from 1980 to 2003 (PECBM 2006). The worst hit habitat in Europe is farmland, with massive population losses all over Europe, including Lake Constance, due to a range of well-known factors (Pain and Pienkowski 1997; Gregory et al. 2004; Bauer et al. 2005b).

At Lake Constance, we have observed an increase and expansion of southerly distributed species and a concurrent decline and loss of northerly distributed species (Lemoine et al. 2007). This seems to be a strong indication of an effect of climate change on the bird community in this prealpine region, as was previously also established in more Atlantic regions of Europe (Thomas and Lennon 1999; Julliard et al. 2003). We suggest that these changes are quite different in more northern parts of Central Europe, and observations on community changes in northern Germany seem to support this (M. Flade, personal communication). Yet, it is still unclear whether climate change can be detrimental to species richness in bird communities at all if immigration of southerly species continues unabated, thus compensating for the loss of northerly distributed species.

In conclusion, the negative local trends in species richness, species abundances, and total biomass clearly give a marked indication of a massive environmental impoverishment in the Lake Constance region. It is evident that only the more abundant Passerine species were hit by a decline in breeding numbers, but not the less abundant Nonpasserines, an aspect rarely reported on in other European regions. This could be due to the fact that Nonpasserine breeding numbers were already at a very low level and could not decline at the same rate, or to the effect of conservation measures favouring Nonpasserines in our region. 
Finally, the analysis of our data made clear that it can be very misleading to imply biodiversity changes from a regional scale without taking recourse to changes in local diversity, population size and biomass.

\section{Zusammenfassung}

Artenzahlen und Bestandsgrößen der Brutvögel im Bodenseegebiet - gegenläufige Langzeittrends bei Singvögeln und Nichtsingvögeln

In den letzten Jahrzehnten wurden in Mitteleuropa gebietsweise erhebliche Verluste im Vogelartenreichtum festgestellt. Doch es stellt sich die Frage, ob diese Abnahme angesichts zunehmender Schutzmaßnahmen weiter anhalten oder eine Trendumkehr feststellbar ist. In der vorliegenden Studie wurde zum einen die Entwicklung des regionalen und lokalen Artenreichtums im Bodenseegebiet über einen Zeitraum von 20 Jahren untersucht, zum anderen die mittlere Brutbestandsgröße aller Arten und die mittlere Biomasse pro Gitterfeld $\left(4 \mathrm{~km}^{2}\right)$. In den drei quantitativen Brutvogelkartierungen des Bodenseegebietes auf 303 Gitterfeldern im Abstand von jeweils 10 Jahren (1980-1981, 1990-1992, 2000-2002) konnte eine Zunahme des regionalen Artenreichtums, d.h. der Gesamtzahl der festgestellten Brutvogelarten, festgestellt werden. Gleichzeitig gab es jedoch einen starken Rückgang im lokalen Artenreichtum, d.h. in der Zahl der Brutvogelarten pro Gitterfeld, in der Zahl der Brutpaare insgesamt sowie in der daraus berechneten Biomasse. Dabei waren die Nichtsingvögel und Singvögel von den Veränderungen des Artenreichtums in unterschiedlicher Weise betroffen. Während der Artenreichtum bei den Nichtsingvögeln von 1980-1990 unverändert blieb und im nachfolgenden Jahrzehnt (1990-2000) sogar zunahm, reduzierte sich die Zahl der Singvogelarten pro Flächeneinheit in beiden Zeiträumen. Diese Ergebnisse weisen darauf hin, dass Einflüsse von Schutzmaßnahmen bei den Nichtsingvögeln die allgemeinen Rückgangsursachen wie Klimaveränderungen und Habitatverluste überdecken. Die massiven Bestands- und Biomasseverluste bei ehemals häufigen Singvogelarten konnten allerdings von den Bestandszunahmen der Nichtsingvögel nicht kompensiert werden. Die Ergebnisse der drei Kartierungen am Bodensee legen nahe, dass die Hauptgründe für die beobachteten Veränderungen neben den zunehmenden Einflüssen des Klimawandels in Habitatveränderungen und -verlusten sowie in anderen menschlichen Einwirkungen zu suchen sind.

Acknowledgements We thank all volunteers of the working group Ornithologische Arbeitsgemeinschaft Bodensee (OAB) for collecting the census data. We thank G. Heine and U. Zeidler for help with the data management, and S. Werner and an anonymous reviewer for valuable comments on the manuscript.

\section{References}

Bauer H-G, Heine G (1992) Die Entwicklung der Brutvogelbestände am Bodensee: Vergleich halbquantitativer Rasterkartierungen 1980/81 und 1990/91. J Ornithol 133:1-22

Bauer H-G, Peintinger M, Heine G, Zeitler U (2005a) Veränderungen der Brutvogelbestände am Bodensee - Ergebnisse der halbquantitativen Gitterfeldkartierung 1980, 1990 und 2000. Vogelwelt 126:141-160

Bauer H-G, Bezzel E, Fiedler W (2005b) Das Kompendium der Vögel Mitteuropas, vol 3. Aula, Wiebelsheim

Berthold P (2001) Bird migration: a general survey. Oxford University Press, Oxford

Bezzel E (1985) Kompendium der Vögel Mitteleuropas: Nonpasseriformes-Nichtsingvögel. Aula, Wiesbaden

Bezzel E (1993) Kompendium der Vögel Mitteleuropas: PasseresSingvögel. Aula, Wiesbaden

BirdLife International (2004) Birds in Europe: population estimates, trends and conservation status. BirdLife International, Cambridge

Böhning-Gaese K (1997) Determinants of avian species richness at different spatial scales. J Biogeogr 24:49-60

Böhning-Gaese K, Bauer H-G (1996) Change in species abundance, distribution, and diversity in a central European bird community. Conserv Biol 10:175-187

Flade M, Schwarz J (2004) Ergebnisse des DDA-Monitoringprogramms, Teil II: Bestandsentwicklung von Waldvögeln in Deutschland 1989-2003. Vogelwelt 125:177-213

Gregory RD, Noble DA, Custance J (2004) The state of play of farmland birds: population trends and conservation status of farmland birds in the United Kingdom. Ibis 146(Suppl 2):1-13

Julliard R, Jiguet F, Couvet D (2003) Common birds facing global changes: what makes a species at risk? Global Change Biol 10:148-154

Lemoine N, Bauer H-G, Peintinger M, Böhning-Gaese K (2007) Effects of climate and land-use change on species abundance in a Central European bird community. Conserv Biol 21:495-503

McKinney ML, Lockwood JL (1999) Biotic homogenization: a few winners replacing many losers in the next mass extinction. Trends Ecol Evol 14:450-453

Møller AP, Fiedler W, Berthold P (eds) (2004) Birds and climate change. Advances in ecological research, vol 35. Elsevier, London

Newton I (2004) The recent declines of farmland bird populations in Britain: an appraisal of causal factors and conservation actions. Ibis 146:579-600

Pain DJ, Pienkowski MW (1997) Farming and birds in Europe: the common agricultural policy and its implications for bird conservation. Academic, London

PECBM (2006) State of Europe's common birds, 2005. CSO/RSPB, Prague

Pimm SL, Jones HL, Diamond J (1988) On the risk of extinction. Am Nat 132:757-785

Sanderson FJ, Donald PF, Pain DJ, Burfield IJ, van Bommel FPJ (2006) Long-term population declines in Afro-Palearctic migrant birds. Biol Conserv 131:93-105

Schuster S (1986) Quantitative Brutvogelbestandaufnahme im Bodenseegebiet 1980 und 1985. J Ornithol 127:439-445

Schuster S, Brall A (2007) Zunahme der Artenvielfalt auf Linientaxierungsstrecken in Südwestdeutschland. Vogelwelt 128:85-91 
Thomas CD, Lennon JJ (1999) Birds extend their ranges northwards. Nature 399:213

Travis JMJ (2003) Climate change and habitat destruction: a deadly anthropogenic cocktail. Proc R Soc Lond B 270:467-473

Walther GR, Post E, Convey P, Menzel A, Parmesan C, Beebee TJC, Frometin J-M, Hoegh-Guldberg O, Bairlein F (2002) Ecological responses to recent climate change. Nature 416:389-395
Zbinden N, Keller V, Schmid H (2005a) Bestandsentwicklung von regelmässig brütenden Vogelarten der Schweiz 1990-2004. Ornithol Beob 102:271-282

Zbinden N, Schmid H, Kéry M, Keller V (2005b) Swiss Bird Index SBI - Kombinierte Indices für die Bestandsentwicklung von Artengruppen regelmässig brütender Vogelarten der Schweiz 1990-2004. Ornithol Beob 102:283-291 